\title{
Factors Affecting Vocational Goal Setting: A Study on Vocational High School Students Tanju DEMIR ${ }^{1}$, Çiğdem AYANOĞLU², Ömer Faruk VURAL ${ }^{3}$
}

\begin{tabular}{l} 
A R T ICLE INFO \\
\hline Article History: \\
Received 15.09 .2020 \\
Received in revised form \\
08.06 .2021 \\
Accepted \\
Available online \\
01.01 .2022
\end{tabular}

\begin{abstract}
In this study, it is aimed to determine the factors that are effective in determining the vocational goals of the students studying at vocational high schools. For this purpose, the study was carried out with 15 students studying at vocational high schools by using case study design, one of the qualitative research methods. The data were obtained through the semi-structured interview form created by the researcher, and the descriptive analysis method was used in the analysis of the data. It has been found that families and friends influence students by supporting them, teachers influence them through counseling, and other people around them influence through validating the professions they choose. In addition, it is another research result that the vocational courses available at the school are effective in choosing a profession. The result that gender is not an effective factor in determining professional goals is one of the important results of the study. It was determined that the students chose the profession they aimed for because they were interested, they believed they would do it fondly, they thought they were talented in their chosen profession and they believed they would be successful.
\end{abstract}

CTUARA Journal. All rights reserved

Keywords:

Professional goal, vocational high school, student

\section{INTRODUCTION}

The individual must produce to survive in society. With the goods and services produced, the division of labor that is obligatory in the society is realized and it provides social and economic gains in return for individuals. This occupation required for division of labor and earning has revealed the phenomenon of profession. Profession is the field of work gained by an education or experience that an individual performs to survive in the community. According to Tan (1992) and Vurucu (2010), many events in the life of individuals such as income level, environment and qualifications, social relations, spouse selection, working conditions, success, happiness, status occur in relation to the occupation. In other words, the choice of profession completely affects the life of the individual. Therefore, the choice of profession is one of the decisions that should be taken by evaluating many aspects in detail. On the other hand, the choice of profession also has a social importance. Community development takes place through the existence of productive individuals and the use of their labor force. The right choices not only make individuals successful, productive, and happy, but also ensure the most efficient use of the workforce. Individuals aim and choose a profession related to their future jobs, especially during their high school years, until their university education. It provides training for both high school and university students for their target profession. Kuzgun (2003) states that preparing students for a profession and strengthening the relations between working life and schools has become one of the increasingly important tasks of education. Education enables the individual to get to know himself / herself and target a profession that is suitable for him / her, as well as to reach sufficient maturity in the targeted profession field. For this reason, high school years are a critical period for the individual to decide on his / her future profession. In this period, the individual determines his / her goal to head towards the profession. According to Kepçeoğlu (1997), goal setting is the first step for students to move towards a profession. It is desirable for a person to turn to a job in which he can make his life happy, have a career and reach his potential to the full. On the other hand, determining professional goals influences increasing school success by providing motivation (Yıldırım, 2016). In reality, the choice of profession starts long before high school years because choosing a profession is not a sudden decision. According to Onur (2004), the choice of profession is not just the individual's decision on the most suitable job for him at that time. Because the choice of profession starts much earlier than when he chose the current job. According to Özgan (2006), career choice is a process

\footnotetext{
${ }^{1}$ Ministry of Education, Turkey, demir.tanju@gmail.com, orcid.org/0000-0003-3658-9286

${ }^{2}$ Ministry of Education, Turkey, cigdemayanoglu@hacettepe.edu.tr, orcid.org/0000-0002-2117-0872

33akarya University, omervural@sakarya.edu.tr, orcid.org/0000-0002-1520-3762
} 
and this process is a long time from the beginning of a career idea in childhood until you have a profession in adulthood. In this case, it is possible to say that the choice of profession may be affected by many factors in this long process. The most important of these are the family, the people with whom the individual has had a relationship until then, the educational background, the individual's needs, interests, abilities, values, the life of the person who is a role model, personality traits, the environment in which he lives, job opportunities and employment conditions can be counted (Yeşilyaprak et al., 1996; Onur, 2004).

The importance of vocational education cannot be denied in raising the qualified manpower needed by countries in the production sector. For this reason, the study was conducted with students from vocational high schools. According to Kantarcioğlu (1987), the choice of profession affects the individual's probability of finding a job, his success and failure, whether he likes his job or not, marriage and social relations. In addition, the choice of profession is a factor that affects how a democratic society will use its manpower. On the other hand, in studies conducted with students, students' vocational and educational goals significantly affect their school achievement (Hall \& Hall, 1976; Sarigiani et al., 1990; Yıldırım, 2016), and It has been concluded that this success increases as a student with a vocational and educational goal gains goal-based motivation (Yildırım, 2016). In this study, it is aimed to determine which factors are affected by students while determining their professional goals due to the importance of the choice of profession that affects individuals' whole lives and society so much. It is hoped that the study will guide school administrations and teachers, families in conjunction with school administrators and teachers to support students in determining professional goals positively. Other objectives of the study are to ensure that students turn to the right professions for them and to increase the motivation of students who determine their professional goals for school success. In this study, which was carried out in order to determine the factors that affect the vocational goals of students studying at vocational high schools, sought answers to the following questions to determine the opinions of the students. While determining the professional goals;

What are the opinions of the students about what factor/factors are effective?

What are their views regarding how their families are effective?

What are their views on how their friends' views are effective?

What are the opinions of the people (other than family, friends and teachers) in their environment about how effective are they?

What are their views on how gender is effective?

\section{METHOD}

The study was conducted using the case study design, one of the qualitative research methods. The case study allows an event or situation to be examined in detail outside the control of the researcher, in other words in its natural environment (Yldırım \& Şimşek 2018). In this direction, the factors that are effective in determining the vocational goals of the students studying at vocational high schools were tried to be determined in detail according to the students' views.

\section{Study Group}

The research was conducted with 15 students from vocational high schools. The study group was determined by using easily accessible sampling method, one of the purposeful sampling methods. Easily accessible sampling method is the selection of the sample that is easy to access by the researcher in order to bring speed and practicality to the research (Yildırım \& Şimşek, 2018). Students in the study group study in the 10th, 11th and 12th grades. There are 8 female and 7 male students in the study group formed with the participation of 5 students from each grade level. The average age of the group is 16 . Code numbers were given to the students as S1, S2, S3, S4, S5, S6, ....... S15. Information on the demographic characteristics of the students participating in the study is presented in Table 1. 
Table 1. Students' demographic characteristics

\begin{tabular}{llll}
\hline Participants & Age & Grade & Gender \\
\hline Student1 & 15 & 10 & Male \\
Student2 & 15 & 10 & Male \\
Student3 & 15 & 10 & Female \\
Student4 & 15 & 10 & Female \\
Student5 & 15 & 10 & Female \\
Student6 & 16 & 11 & Male \\
Student7 & 16 & 11 & Female \\
Student8 & 16 & 11 & Female \\
Student9 & 16 & 11 & Male \\
Student10 & 16 & 11 & Male \\
Student11 & 17 & 12 & Male \\
Student12 & 17 & 12 & Female \\
Student13 & 17 & 12 & Female \\
Student14 & 17 & 12 & Female \\
Student15 & 17 & Male \\
\hline
\end{tabular}

\section{Material}

A semi-structured interview form consisting of open-ended questions was used as a data collection tool in the study. Interview questions were created by evaluating the themes obtained by the research of the literature on the choice of profession, factors affecting the choice of profession, vocational guidance, which were made separately by the researchers. In line with the determined common themes, 7 open-ended questions covering the literature and expressing the research problem best were determined. According to Yıldırım and Şimşek (2018), open-ended questions used in research allow the subject or phenomenon to be handled with a flexible approach and to obtain in-depth information about the subject and phenomenon.

The data were obtained through face-to-face interviews with students who volunteered to participate in the study. The answers given to the interview questions were recorded with the Microsoft Word- word processor program in order to prevent data loss.

\section{Data Analyses}

Descriptive analysis technique was used in the analysis of research data. The descriptive analysis technique consists of four stages: creating a framework, processing the data according to the thematic framework created, describing the findings and interpreting the findings (Yıldırım \& Şimşek, 2018). A thematic framework was determined by coding the answers of the students independently in different environments and times by each researcher. Afterwards, the researchers came together and determined the ones that showed similarities from the codes they evaluated and reached a consensus on them. Using the code list, the data were tabulated by determining which student gave an opinion on which theme and code within the framework of certain themes and codes. In order to facilitate the interpretation of the findings by the readers, direct quotations were provided from the answers given to the questions by the students. The answers given to the interview questions and the findings obtained as a result of the analysis were examined by an independent researcher to ensure the reliability of the study. The final form of the findings was determined by evaluating the feedback received from the independent researcher.

\section{FINDINGS}

\section{Findings regarding the students' views on the factors affecting the determination of professional goals}

Findings regarding the opinions of the students regarding the factors that affect their professional goals are presented in Table 2 . 
Table 2. Students' opinions about which factor is effective in determining their professional goals

\begin{tabular}{clcc}
\hline Theme (Categories) & \multicolumn{1}{c}{ Codes } & $n$ & $\%$ \\
\hline & School (S1, S2, S6, S10, S11, S12, S13, S14) & 8 & 53,3 \\
The Factor Effective & Personal requests and preferences (S1, S2, S3, S6, S10, S11) & 6 & 40 \\
in Determining & Professionals in the immediate vicinity (S6, S8, S10) & 3 & 20 \\
Professional Goals & Family request (S6, S11) & 2 & 13,3 \\
& Friends (S9) & 1 & 6,6 \\
\hline
\end{tabular}

In Table 2, it is seen that most of the students (53.3\%) participating in the study stated that the school they studied at was an effective factor in determining their professional goals. $6(40 \%)$ of the students stated that their personal wishes and preferences, $3(20 \%)$ of them the professionals in their close circle, 2 $(\% 13,3)$ of them family wishes and $1(\% 6,6)$ of them their friends were effective factors in determining their professional goals. Some of the expressions of the students' views are quoted exactly and presented below.

"The school helped me understand what I would like to do". (S10)

"I chose the things that can make me happy according to my own wishes." (S3)

"My family has an influence because they want to see me as a healthcare employee." (S6)

"My group of friends also said it was a good job. They supported me behind." (S9)

"It had an impact because I have my sports teachers and brothers and sisters studying at school of physical education and sports." (S8)

Findings on the opinions of the students on the reasons for choosing their target profession

Findings on the opinions of the students regarding the reasons for choosing the profession they target are presented in Table 3.

Table 3. Students' opinions on the reasons for choosing their target profession

\begin{tabular}{llcc}
\hline Theme (Categories) & \multicolumn{1}{c}{ Codes } & $n$ & $\%$ \\
\hline & Interest in chosen profession (S4, S5, S6, S7, S8) & 5 & 33,3 \\
Reason for Choosing & The belief of loving the chosen profession (S3, S7, S8, S14) & 4 & 26,6 \\
the Target Profession & Thought of being talented in the chosen profession (S12, S13) & 2 & 13,3 \\
& Belief of being successful in the chosen profession (S11, S15) & 2 & 13,3 \\
\hline
\end{tabular}

In Table 3, it is seen that 5 of the students (33.3\%) were interested in the profession they chose, $4(26.6 \%)$ believed they would do the profession they chose fondly, $2(13.3 \%)$ thought they were talented in their chosen profession and 2 of them (13.3\%) stated that they chose their target profession because they believed that they would be successful in their profession. Some of the expressions of the students' views are quoted exactly and presented below.

\footnotetext{
"I want to be a psychologist because I'm interested in understanding people." (S4)

"I want to be a policeman. I think it is a profession that is suitable for me and I can do fondly." (S7)

"I think I am talented." (S12)

"I think it will suit me and I will be successful." (S15)
} 
Findings based on the students' views on how their families are effective in determining their professional goals

Findings on the opinions of the students regarding the direction of their families while determining their professional goals are presented in Table 4.

Table 4. Students' views on how their families are effective in determining their professional goals

\begin{tabular}{clcc}
\hline Theme (Categories) & \multicolumn{1}{c}{ Codes } & $n$ & $\%$ \\
\hline & Family support for the chosen profession (S1, S2, S3, S5, S7, S8, S9, & 11 & 73 \\
& S12, S13, S14, S15) & 2 & 13,3 \\
The Influence of the & Family determine the profession (S6, S11) & 1 & 6,6 \\
Family in Setting the & Family oppose the chosen profession (S4) & 1 & 6,6 \\
Professional Goals & Family does not interfere with the student in the choice of & 1 \\
& profession. (S10) & & \\
\hline
\end{tabular}

In Table 4, it is seen that most of the students (73\%) stated that their families supported the professions they chose while determining their professional goals. In addition, it is seen that 2 of the families (13.3\%) determined the profession chosen by the students themselves, $1(6.6 \%)$ opposed the profession chosen by the student, and 1 (6.6\%) did not interfere with the student in the choice of profession. Some of the expressions of the students' views are quoted exactly and presented below.

"They respected my decision, gave confidence and support." (S2)

"My family set my goal." (S11),

"They got angry, but it is my life, it is my decision." (S4)

"My family had almost no effect." (S10)

Findings on the views on how effective the school where students are studying while determining their professional goals Findings on the opinions of the students regarding the effect of the school where they study while determining their professional goals are presented in Table 5.

Table 5. Students' views on how the school they study is effective in determining their professional goals

\begin{tabular}{clcc}
\hline Theme (Categories) & \multicolumn{1}{c}{ Codes } & n & o \\
\hline School Effect in & Teacher guidance (S1, S10, S12, S13, S14) & 5 & 33,3 \\
Setting Vocational & No effect (S5, S7, S8, S9, S15) & 5 & 33,3 \\
Goals & Profession-related lessons (S2, S6, S11) & 3 & 20 \\
\hline
\end{tabular}

In Table 5 , it is seen that $5(33.3 \%)$ of the students participating in the study stated that their teachers' guidance and $3(20 \%)$ of them stated that the courses related to the profession in the school were effective in determining professional goals. On the other hand, $5(33.3 \%)$ of the students stated that the school had no effect on determining professional goals. Some of the expressions of the students' views are quoted exactly and presented below.

"When I tell my teachers, they tell me what to do, they help me." (S1)

"The school had no effect. I researched it myself and found it suitable for me." (S9)

"Lessons taken has an effect on determining professional goal." (S2)

Findings on students' views on how their peers are effective in determining their professional goals Findings on the opinions of the students about how their friends are effective while determining their professional goals are presented in Table 6. 
Table 6. Students' opinions about how their peers were effective while determining their professional goals

\begin{tabular}{clcc}
\hline Theme (Categories) & \multicolumn{1}{c}{ Codes } & $n$ & $\%$ \\
\hline The Influence of & Support (S1, S4, S5, S6, S7, S9, S12, S13, S14) & 9 & 60 \\
Friends in Setting & No effect (S2, S3, S8, S10, S11, S15) & 6 & 40 \\
Occupational Goals & & & \\
\hline
\end{tabular}

In Table 6, it is seen that $9(60 \%)$ of the students stated that their friends supported them in determining their professional goals, and $6(40 \%)$ of them stated that their friends had no effect. Some of the expressions of the students' views are quoted exactly and presented below.

"I think they were happy, because they were always behind me." (S4)

"My friends has no effect on this decision." (S2)

Findings on students' views on how the people in their environment (family, friends and people other than teachers) are effective in determining their professional goals. Findings on the opinions of the students about how the people in their environment (family, friends and people other than teachers) are effective while determining their professional goals are presented in Table 7.

Table 7. Students' opinions about how the people in their environment (family, friends and people other than teachers) are effective in determining their professional goals

\begin{tabular}{|c|c|c|c|}
\hline Theme (Categories) & Codes & $n$ & $\%$ \\
\hline $\begin{array}{l}\text { The Influence of the } \\
\text { People Around Them in }\end{array}$ & $\begin{array}{l}\text { Approval of the chosen profession (S1, S5, S6, S7, S8, S9, S10, } \\
\text { S12, S13, S14) }\end{array}$ & 11 & 73,3 \\
\hline $\begin{array}{l}\text { Determining Professional } \\
\text { Goals }\end{array}$ & No effect (S2, S3, S11, S15) & 4 & 26,6 \\
\hline
\end{tabular}

In Table 7, it is seen that, $11(73.3 \%)$ of the students stated that other people around them, except their family, friends and teachers, approved the profession they chose, and $4(26.6 \%)$ of them stated that the people around them had no influence. Some of the expressions of the students' views are quoted exactly and presented below.

"People around me said this profession was suitable for me." (S5)

"The people around me had no effect." (S2)

Findings on students' views on how their gender is effective in determining their professional goals

Findings on the opinions of the students about how their gender is effective while determining their professional goals are presented in Table 8. 
Table 8. Students' opinions on how their gender affects their professional goals

\begin{tabular}{clcc}
\hline Theme (Categories) & \multicolumn{1}{c}{ Codes } & $n$ & $\%$ \\
\hline The Effect of Gender & No effect (S1, S2, S4, S5, S6, S7, S9, S10, S11, S14, S15) & 11 & 73,3 \\
in Setting Vocational & Being a male (S3, S8) & 2 & 13,3 \\
Goals & Being a female (S12, S13) & 2 & 13,3 \\
\hline
\end{tabular}

In Table 8 , it is seen that 11 of the students $(73.3 \%)$ think gender is an important factor on determining their professional goals, while $2(13.3 \%)$ of them see being a male and $2(13.3 \%)$ of them see being a female as an important factor. Some of the expressions of the students' views are quoted exactly and presented below.

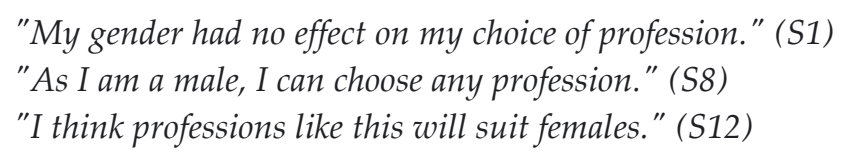

\section{RESULT, DISCUSSION AND SUGGESTIONS}

According to the opinions of the students studying at vocational high schools, the following results were obtained in this study, which was carried out to determine the factors that affect their professional goals: School and family are effective factors in determining professional goals. Students set their professional goals because they are interested in them, they believe they will do them with love, they think they are talented in their chosen profession, and they believe they will be successful. Most families supported students in the professions they chose while determining their professional goals. The school the students' study at, guidance of their teachers and the vocational lessons they study at school affects the opinions of the students while determining their Professional goals. Friends supported the students about the professions they chose while determining their professional goals. Apart from family, friends and teachers, other people around them supported students by approving the professions they chose while determining their professional goals. Gender is not an effective factor in professional goal setting.

The conclusion that the school and the family are effective factors in the process of determining the professional goals of the students coincides with the results of many studies in the literature. According to Gezer (2010), the choice of profession, which is important in the life of the individual, is under the influence of many factors. According to Gezer (2010), the choice of profession, which is important in the life of the individual, is affected by many factors. Students' family and close environment are among the factors that are effective in determining their professional goals. According to Binici and Ar1 (2004), school, family and students should cooperate in directing students to the professions they are prone to. Kepçeoğlu (1997) states that one of the sociological factors affecting the choice of profession is the family. While the family can directly affect the students in the career choice process, the students' acquisition of their decision-making skills in the family also affects this choice. According to Brown and Mann (1990), the most important factor in the development of decision-making ability is family. Seeing the results of the choices of family members of the children is effective in determining criteria when making choices about themselves (cited in Eldeleklioğlu, 1996). For this reason, the decision-making ability developed by the student is also important and effective in choosing a profession. In the study conducted by Vurucu (2010), it was concluded that the school and the teachers were also influential in the choice of profession in addition to the expectations of the families according to the students' opinions. Yıldırım (2016) stated that it is important for teachers to consider their students' professional and educational goals and to support students in this regard. Counselors should discover the individual differences between students, explain the positive findings to students, and conduct various guidance activities for the development of students' abilities (Rader, 2005; Given 2006; Aydın, 2010, Robinson and Gahagan, 2010). It can be said that guidance activities performed successfully will support students in determining professional goals.

In the study, it was concluded that while determining the professional goals of the students, besides the influence and support of their family and school, friends and other people around them were also influential. The students stated that not only their families, friends and teachers but also other people around them approve and support them in their choice of profession. In parallel with these results, in the study conducted 
by Vurucu (2010), it was determined that students' friends and environment were effective in their professional goals. Again, in the study conducted by Özgüven (2001), it was determined that the family, environment and social environment have effects on students' choice of profession. This effect appears as being under the influence of people working in any profession, choosing the profession of a relative, or accepting the profession decision made by the parents for them. Family, close friends, and other people with whom they have close relationships are sociological factors affecting the choice of profession (Kepçeoğlu, 1997). Lion (1952) explains professional goal orientation, communication with his parents, teachers and friends, as a dialectic between their interests and knowledge (cited in Onur, 1987). According to Koç (2003), an individual is a social entity that is affected by the society $\mathrm{s} /$ he is in. For this reason, it is normal to see this effect on students' choice of profession.

The professions targeted by the students in the research; It was determined that they chose them because they were interested, they believe they will do it fondly, they think they are talented in that field and they believe they will be successful. In the study conducted by Gezer (2010), it was determined that besides the effect of family and close environment, the basic abilities and interests of the person are also an effective factor in students' choice of profession. According to Rogers, if an individual chooses a profession suitable for their personality traits, interests and abilities, they will be able to develop their hidden powers and be fully active. In other words, it will be able to realize himself (cited in Gezer, 2010). The choice of profession is the orientation of the individual to a field where he can lead his life happily and successfully, and realize himself (Kepçeoğlu, 1997). It should not be forgotten that individuals who choose their profession knowing their interests and skills do their jobs willingly and happily. As the wise-philosopher Confucius said; "If you do what you love, you won't be working even a day".

Another result of this study is that gender (Marshall, 1999), which indicates the differences in hereditary, vital and physical characteristics formed by the individual in the form of male or female, is not an effective factor in determining students' professional goals. The result of the study by Kuzgun (2000) that social judgments about gender roles are effective in choosing a profession contradicts with the result of this study. Individuals are guided to different professions by both their families and the society because of their gender, and individuals choose a profession under the influence of these stereotypes. Another study on this subject revealed that the majority of students had the opinion that they wanted to work in a profession suitable for their gender (Gezer, 2010). It can be said that the current research does not confirm the general opinion formed by these studies in the literature.

\section{Suggestions}

The school guidance services should guide families who will support their children in determining their professional goals starting from the preschool period. School / classroom activities should be organized at all educational levels to highlight the interest and ability of the student. Occupational guidance activities such as vocational promotions, career days, higher education institution promotions, career planning services should be carried out in schools. With a wider sample group, quantitative and mixed studies can be conducted to determine the factors that affect students' professional goal setting.

\section{REFERENCES}

Aydın, G. (2010). 7.sınıf öğrencilerinin daha gelişmiş zekâ alanlarının saptanması ve buna uygun çoklu zekâ kuramı etkinlikleri ile öğretim yapılması. (Yayın No. 278125) [Yüksek Lisans tezi, Gazi Üniversitesi]. Ulusal Tez Merkezi.

Binici, H. \& Arı, N. (2004). Meslekî ve teknik eğitimde arayişlar. Gazi Eğitim Fakültesi Dergisi, 24(3), 383-396. http://www.gefad.gazi.edu.tr/tr/pub/issue/6758/90909

Eldeleklioğlu, J. (1996). Karar stratejileri aile ana baba tutumları arasındaki ilişkiler. (Yayın No. 52683) [Doktora tezi, Ankara Üniversitesi]. Ulusal Tez Merkezi.

Gezer, M. (2010). Kariyer planlanmasında meslek seçiminin önemi: meslek lisesi son sinıf öğrencileri üzerine bir araştırma. (Yayın No. 273031) [Yüksek lisans tezi, Sakarya Üniversitesi]. Ulusal Tez Merkezi. 
Given, B.K. (1996). Learning styles: A synthesized model. Journal of Accelerated Learning and Teaching, 21(1\&2), 11- 43. https://files.eric.ed.gov/fulltext/ED436959.pdf

Hall, D. T. \& Hall, F. S. (1976). The relationship between goals, performance, success, self-image, and involvement under different organization climates. Journal of Vocational Behavior, 9(3), 267-278. https://doi.org/10.1016/0001-8791(76)90055-5

Kantarcıoğlu, S. (1987). Rehberlik el kitabı. Millî Eğitim Bakanlığı.

Kepçeoğlu, M. (1997). Rehberlik ve psikolojik danışma. Alkım.

Koç, M. (2003). Rehberlik (Nurten Sargın, Ed.). Mikro.

Kuzgun, Y. (2000). Meslek danışmanlığı kuramlar ve uygulamalar. Nobel.

Kuzgun, Y. (2003). Meslek rehberliği ve danışmanlığına giriş. Nobel.

Marshall, G. (1999). Sosyoloji sözlü̆g̈ü. Osman Akınhay \& Derya Kömürcü (Çev.). Bilim ve Sanat.

Onur, B. (1987). Ergenlik psikolojisi. İmge.

Onur, B. (2004). Gelişim psikolojisi. İmge.

Özgan, A. (2006). Meslek lisesi öğrencilerinin mesleki karar verme olgunluğu ile bazı kişilik özelliklerinin incelenmesi. (Yayın No. 185172) [Yüksek Lisans tezi, Marmara Üniversitesi]. Ulusal Tez Merkezi.

Özgüven, E. (2001). Çağdaş eğitimde psikolojik danışma ve rehberlik. Pederem.

Rader, L.A. (2005). Goal setting for students and teachers-six steps to success. The Clearing House, 78(3), 123126. https://www.jstor.org/stable/30190034

Robinson, C. \& Gahagan, J. (2010). Coaching students to academic success and engagement on campus. About Campus, 15(4), 26-29. https://doi.org/10.1002/abc.20032

Sarigiani, P. A., Wlson, J. L., Petersen, A. C. \& Vicary, J. R. (1990). Self-Image and educational plans of adolescents from two contrasting communities. The Journal of Early Adolescence, 10(1), 37-55. https://doi.org/10.1177/0272431690101003

Tan, H. (1992). Psikolojik danışma ve rehberlik. Millî Eğitim Bakanlığı.

Vurucu, F. (2010). Meslek lisesi öğrencilerinin meslek seçimi yeterliliği ve meslek seçimini etkileyen faktörler. (Yayın No. 249055) [Yüksek Lisans tezi, Yeditepe Üniversitesi]. Ulusal Tez Merkezi.

Yeşilyaprak, B., Kurç, G. \& Güngör, A. (1996). Eğitsel ve mesleki rehberlik. Varan.

Yıldırım, A. \& Şimşek, H. (2018). Sosyal bilimlerde nitel araştırma yöntemleri. Seçkin.

Yıldırım, M. (2016). Lise öğrencilerinde kendilik imgesinin okul başarısına etkisi. Marmara Üniversitesi Atatürk Eğitim Fakültesi Eğitim Bilimleri Dergisi, 43, 157-168. https://dergipark.org.tr/tr/pub/maruaebd/issue/23602/251277 